Volume 3 Issue 2 (2019) Pages 425-432

Jurnal Obsesi : Jurnal Pendidikan Anak Usia Dini

DOI: $10.31004 /$ obsesi.v3i2.228

\title{
Meningkatkan Kemampuan Berpikir Kritis melalui Pendekatan Saintifik
}

\author{
Herina Yunita ${ }^{1}{ }^{凶}$, Sri Martini Meilanie ${ }^{2}$, Fahrurrozi $^{3}$ \\ Pendidikan Anak Usia Dini, Universitas Negeri Jakarta
}

\begin{abstract}
Abstrak
Penelitian ini bertujuan untuk meningkatkan kemampuan berfikir kritis anak kelas B2 di TK Pertiwi 3 Palembang. Metode penelitian yang digunakan yaitu penelitian tindakan kelas yang dilakukan secara kolaboratif antara peneliti dan guru kelas. Subjek dalam penelitian ini adalah anak kelompok B2 TK Pertiwi 3 kota Palembang yang berjumlah tujuh belas orang anak. Teknik pengumpulan data melalui observasi dan dokumentasi. Teknik analisis data dilakukan dengan deskriftif kualitatif. Berdasarkan data yang diperoleh presentase keampuan berfikir kritis anak pada pra siklus sebesar lima puluh persen. Pada Pra siklus kemampuan berfikir kritis anak berada pada kategori mulai berkembang (MB). Pada siklus I (TCP) kemampuan berfikir kritis anak berada pada kategori berkembang sesuai harapan (BSH). Pada siklus II tingkat capaian anak rata-rata berada pada kategori berkembang sangat baik (BSB). Terlihat adanya peningkatan kemampuan berfkir kritis anak meningkat mulai dari pra siklus, siklu I, dan siklus II.
\end{abstract}

Kata Kunci: pendekatan saintifik; berfikir kritis; anak usia dini

\begin{abstract}
This study to improve the critical thinking skills of class B2 children at TK Pertiwi 3 Palembang. The research method used is classroom action research conducted collaboratively between researchers and classroom teachers. The subjects in this study were children in group B2 TK Pertiwi 3 in Palembang, which numbered seventeen children. The technique of collecting data through observation and documentation. Data analysis techniques are carried out with qualitative descriptive. Based on the data obtained the percentage of children's critical thinking ability in the pre-cycle of fifty percent. In the first cycle, children's critical thinking skills are in the developing category (MB). In the first cycle (TCP) critical thinking skills of children are in the developing category according to expectations (BSH). In the second cycle the average level of achievement of children is in the very good developing category (BSB). It can be seen that there is an increase in the ability of children to be critical, starting from precycle, cycle I, and cycle II.
\end{abstract}

Keywords: saintifics approach; critical thinkin; early childhood education

Copyright (c) 2019 Herina Yunita, Sri Martini Meilanie, Fahrurrozi

$\triangle$ Corresponding author :

Address : Jl. Pemuda 1 Rawamangun Jakarta Timur

ISSN 2356-1327 (Media Cetak)

Email : herinayunita@gmail.com

ISSN 2549-8959 (Media Online) 


\section{PENDAHULUAN}

Pada Pendidikan abad 21, anak sebaiknya mampu melihat keterkaitan antara apa yang mereka pelajari dengan kenyataan yang mereka lihat pada lingkungan sekitar mereka. Anak sebaiknya dapat menggunakan perangkat atau pirantipiranti yang mereka perlukan untuk menggambarkan lingkungan pekerjaan yang nyata agar mereka mendapatkan keahlian-keahlian yang diperlukan pada level yang tinggi sebagaimana yang diharapkan dari mereka untuk menghadapi tantangan abad 21. Pendidikan yang mengacu pada tantangan abad 21 di perlukan untuk mempersiapkan anak untuk menjadi sumber daya manusia yang berkualitas.

Pendidikan berperan penting untuk membentuk pola pikir. Selain membentuk pola pikir pendidikan juga, membuat wawasan seseorang semakin berkembang. Pendidikan dalam konteks mempersiapkan sumber daya manusia untuk menghadapi tantangan abad 21 harus lebih mengacu pada konsep belajar yang dicanangkan komisi unesco dalam wujud "the four pillars of education" (Azizah \& Edie, 2014). Pendidikan tidak hanya untuk usia dewasa, tetapi pendidikan sudah dimulai sejak dalam kandungan.

Tahun 2014 sampai tahun 2019 perkembangan anak terjadi sangat pesat, salah satunya adalah kemampuan kognitif anak. Perkembangan kognitif, merupakan salah satu aspek yang cukup intensif dikembangkan pada anak usia dini di Indonesia. Hal ini dikarenakan masih banyak orang tua yang beranggapan bahwa anak yang memiliki kemampuan kognitif yang tingga dianggap sebagai anak cerdas yang akan berhasil pada kehidupannya kelak. (Tatminingsih, 2019)
Kemampuan kognitif ini berkembang secara bertahap sejalan dengan perkembangan fisik dan saraf yang berada di pusat susunan saraf. (Menkes, 2015) Kemampuan kognitif yang perlu di asah anak adalah semenjak dini adalah kemampuan berpikirnya. Berpikir merupakan salah satu bagian dari kemampuan kognitif tingkat tinggi yang harus di asah sedini mungkin, salah satu bagian kemampuan kognitif tingkat tinggi yaitu berpikir kritis. Kemampuan berpikir kritis anak dapat dilhat dari pertanyaan tentang hal-hal yang kita anggap tidak akan di tanyakan oleh anak, tentang hal baru yang muncul dan ditanyakan oleh anak di lingkungan sekitarnya.

Menurut Lipman (Moore, 2005) ada perbedaan antara berpikir dan berfikir kritis, yaitu ordinary thingking is usually simpel and lacks standards,whereas critical thinking is more complex and based upon standards of objectivity and consistency. Menurut pendapat Lipman di atas berpikir kritis memiliki nilai kompleksitas yang tinggi dan juga konsistensi, sehingga tingkat kemampuan berpikirnya jauh lebih tinggi dibandingkan dengan berpikir saja. Kegiatan berpikir biasa tidak terlalu banyak melibatkan aktifitas kognitif tingkat tinggi seperti menganalisis, mensintesis, menyimpulkan, dan mengevaluasi.

Tujuan mengasah kemampuan berpikir kritis pada anak yaitu mendidik anak untuk mengkomunikasikan pemikirannya, menyelesaikan permasalahan serta dapat memilah informasi yang diterima. Selain itu dengan di ajarkan berfikir kritis sejak dini anak di harapkan dapat menjadi pribadi yang lebih teliti, tidak mudah menyerah serta bertangung jawab.

Saat penulis melakukan observasi, pembelajaran yang di lakukan di TK tersebut anak hanya mendengarkan dan menerima informasi tanpa melalui kegiatan, 
mengamati, menganalisis, dan menyimpulkan kegiatan yang mereka lakukan pada akhir pembelajaran. Sehingga kemampuan berpikir kritis anak kurang terasah secara maksimal. Kegiatan pembelajaran di TK tersebut terkesan monoton karena masih didominasi Teacher Center yaitu, guru memberikan penjelasan dan anak hanya mendengarkan tanpa ada kegiatan menstimulus anak untuk aktif berfikir, dan berekspolari dalam kegiatan pembelajaran.

Untuk mengatasi permasalahan di atas peneliti tertarik untuk menerapkan pendekatan saintifik (saintifik Approach) untuk meningkatkan kemampuan berfikir kritis anak. Munawaroh berpendapat bahwa Pendekatan saintifik tidak diartikan sebagai belajar sains tetapi menggunakan proses saintifik dalam kegiatan belajar.pembelajaran dengan pendekatan saintifik dilakukan dalam suasana yang menyenangkan karena melibatkan anak secara langsung dalam proses pembelajaran dan memberikan kesempatan penuh pada anak untuk mencoba dan menemukan sendiri pengetahuannya. (Munawaroh \& Retyanto, 2016)

Melalui pendekatan saintifik anak diajak untuk melakukan kegiatan yang berhubungan dengan dikenalkan pada pendekatan ilmiah fenomena di sekitarnya. Hal ini didukung dengan adanya kenyataan bahwa anak usia dini sangat antusias berekspolarasi tanpa memiliki rasa takut (Science \& Standards, 1996)

Seperti apa yang dikemukakan oleh Ducworth (Kemdikbud, 2008) bahwa pada anak usia dini pengenalan proses saintifik dilakukan dengan cara melibatkan anak langsung di dalam kegiatan; yakni melakukan pencarian informasi hingga memahami dunia dengan gagasan yang menabjubkan.
Kegiatan saintifik baik untuk mengembangkan kemampuan mengamati, menyelidiki, memiliki keterampilan proses, mampu bersosialisasi, dan membangkitkan motivasi dan rasa ingin tahu anak dengan cara yang aktif dan menyenangkan tanpa melupakan prinsip dasar anak usia dini yaitu belajar sembari bermain dan bermain sembari belajar karena, bermain merupakan bagian yang tidak dapat dipisahkan dari anak.

Pendekatan saintifik mengacu pada pendekatan ilmiah. Pelaksanaan pendekatan ilmiah beruapaya membangun suasana yang menyenangkan untuk menarik minat anakanak. Pendekatan ilmiah mampu membangun kreativitas, imajinasi dan ide yang mengembangkan nilai-nilai agama dan moralitas, motorik, kognitif, bahasa, sosial, emosional dan seni berdasarkan pada prinsip-prinsip perkembangan anak. Oleh karena itu, pelaksanaan pendekatan ilmiah dalam proses pembelajaran pendidikan anak usia dini dapat mengasah kecerdasan spiritual dan intelektual anakanak.(Munastiwi, 2015)

Selaras dengan permasalahna di atas, hasil penelitian dari setiawan, Hafitri, Prabawa (2016) dengan judul penelitian The scientific approach using learning multimedia based-maze game to improve learning outcomes menjelaskan bahwa pendekatan saintifik dalam proses pembelajaran melalui game maze dapat menjadikan pembelajaran lebih bermakna dan secara langsung dapat mengaitkan materi pembelajaran dalam kehidupan sehari-hari anak. Yassir Semar (2009) menemukan efek positif terhadap pencapaian akademik siswa dengan dikembangkannya kemampuan berpikir kritis di sekolah.

Namun demikian memiliki kemampuan berpikir kritis rendah tidak menjadi penghalang untuk meningkatkan 
keterlibatan anak dalam proses pembelajaran akan tetapi dibutuhkan model pembelajaran yang sesuai dan tepat. (Dewi, Hapidin, \& Akbar, 2019)

Penelitian lain tentang berpikir kritis pada anak usia dini juga telah dilakukan oleh Salmon and Luca (2011) untuk melihat pengaruh penerapan guru terhadap kemampaun berpikir kritis anak di Harvard Graduate School untuk pendidikan usia dini. Hasil menunjukan bahwa kegiatan mengeksplorasi yang dilakukan selama enam bulan tentang bagaimana konsep berpikir dikembangkan, yang melibatkan sepuluh orang guru dan anak dengan rentang umur tiga sampai lima tahun, penelitian ini menunjukkan bahwa anakanak dengan guru yang menerapkan kemampuan berpikir mengalami peningkatan terhadap kemampuan berpikir anak.

Penelitian yang dilakukan oleh Atik Watini mengembangkan kemampuan berpikir secara krtitis dengan menggunakan pendekatan pembelajaran discovery-inquiry yang menekankan pada proses berpikir secara kritis dan analitis untuk mencari dan menemukan sendiri jawaban dari suatu masalah terbukti dapat dilakukan. (Wartini, Hadi al-asy'ari, \& Multahada, 2017)

\section{METODOLOGI}

Jenis penelitian ini adalah penelitian tindakan kelas (PTK) yang dilakukan secara kolaboratif antara peneliti dan guru kelas. Penelitian ini dilakukan di Kelas B2 TK Pertiwi 3 Palembang. Jumlah anak dalam satu kelas sebanyak 17 orang anak, terdiri dari 11 anak laki-laki dan 6 anak perempuan. Pengumpulan data dalam penelitian ini menggunakan instrument penelitian observasi dan dokumentasi. Berikut kisi-kisi penilaian
Tabel 1. Penilaian Kemampuan berfikir kritis anak melalui pendekatan saintifik

\begin{tabular}{|c|c|c|}
\hline No & Aspek & Indikator \\
\hline \multirow[t]{3}{*}{1} & \multirow{3}{*}{$\begin{array}{l}\text { Memperhatika } \\
\mathrm{n} \text { (observasi) }\end{array}$} & 1. Melakukan pengamatan \\
\hline & & 2. Mengajukan pertanyaan \\
\hline & & $\begin{array}{l}\text { 3. } \\
\text { pengemukakan } \\
\text { informasi baru yang } \\
\text { didengar dan dilihat }\end{array}$ \\
\hline \multirow[t]{2}{*}{2} & \multirow{2}{*}{$\begin{array}{l}\text { Merumuskan } \\
\text { Masalah } \\
\text { (mengkategori } \\
\text { kan) }\end{array}$} & $\begin{array}{l}\text { 4. Menghubungkan sebab } \\
\text { akibat }\end{array}$ \\
\hline & & $\begin{array}{l}\text { 5. Mengelompokan } \\
\text { berdasarkan jenisnya }\end{array}$ \\
\hline \multirow[t]{3}{*}{3} & \multirow{3}{*}{$\begin{array}{l}\text { Menganali-sis } \\
\text { (menyelek-si ) }\end{array}$} & 6. Melakukan percobaan \\
\hline & & 7. Menemukan perbedaan \\
\hline & & 8. Menemukan persamaan \\
\hline \multirow[t]{2}{*}{4} & \multirow[t]{2}{*}{$\begin{array}{l}\text { Menggeva- } \\
\text { luasi }\end{array}$} & $\begin{array}{l}\text { 9. Menyiapkan alternatif } \\
\text { lain dalam } \\
\text { menyelesaikan masalah }\end{array}$ \\
\hline & & $\begin{array}{l}\text { 10. Menyimpulkan hasil } \\
\text { kegiatan }\end{array}$ \\
\hline
\end{tabular}

Data kuantitatif yaitu hasil yang diperoleh anak dalam pembelajaran melalui pendekatan saintifics untuk meningkatkan kemampuan berfikir kritis yang dinilai obeserver dengan menggunakan lembar observasi. Data hasil penilaian kemampuan berfikir kritis anak yang dianalisis dengan melakukan perbandingan data kondisi awal penelitian dan data hasil akhir penelitian yang diperoleh setelah pelaksanaan penelitian yang dilakukan antara peneliti dan kolaborator (guru dan kepala sekolah) pada anak. Hasil yang dimaksud meliputi nilai yang diperoleh saat pra siklus hingga akhir siklus. Nilai rata-rata tersebut disajikan dalam bentuk tabel dan grafik yang menggunakan rumus (Ngalim, 2011) $\mathrm{S}=\frac{R}{N} \times 100 \%$

Keterangan:

$\mathrm{S}=$ Nilai yang dicapai

$\mathrm{R}=$ Jumlah skor item soal yang benar

$N=$ Skor maksimal 


\section{HASIL DAN PEMBAHASAN}

\section{Hasil Penelitian}

Pada pra siklus, peneliiti menemukan permasalahan pada kemampuan berfikir kritis anak. Dimana masih banyak anak yang kurang mengobservasi atau mengamati, kurang dalam merumuskan, mmenganalisis dan mengevaluasi suatu masalah. Setelah menemukan fokus permasalahan, maka peneliti fokusmengamati kemampuan berfikir kritis anak. Hasil wawancara dengan guru kelas juga menguatkan masalah yang terjadi di lapangan. Jika banyak anak yang kemampuan berfikir kritisnya masih kurang.

\section{Pra Siklus}

Dari data Pra siklus menunjukan skor awal kemampuan berfikir kritis anak dengan rata-rata presentase yaitu $50 \%$. Presentase tertinggi dari keseluruhan aspek penilaian pra siklus kemampuan berfikir kritis dimiliki oleh FP $68,75 \%$ dan AR 70,83 .

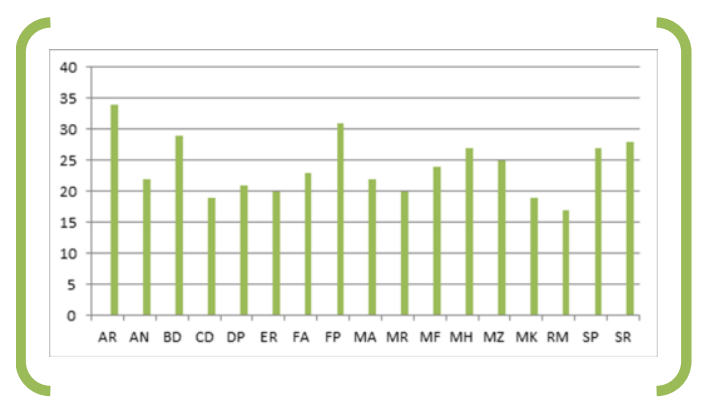

\section{Grafik 1: Data kemampuan pra siklus berfikir kritis}

Berdasarkan data observasi pra siklus, yang telah di paparkan melalui data kualitaatif , peneliti dan kolaborator menyimpulkan perlu adanya tindakan yang dirancang serta diharapkan mampu meningkatkan kemampuan berfikir kritis anak. Tindakan tersebut disepakati menggunakan pendekatan saintifik karena pendekatan saintifik merupakan proses pembelajaran yang dirancang agar anak secara aktif membangun sendiri pengetahuannya, sehingga pentingnya intervensi yang dilakukan diharapkan dapat mengasah kemampuan berfikir kritis anak.

\section{Siklus I}

Berdasarkan hasill siklus I yang dilaksanakan selama 8 kali pertemuan, diketahui bahwa tingkat capaian perkembanagn (TCP) kemampuan berfikir kritis anak skor rata-ratanya sebear 67 dengan kategori berkembang sesuai harapan (BSH) dalam hal ini terdapat tiga orang anak yang yang memiliki TCP di atas 75 dan 15 orang anak yang berada pada TCP di bawah 75 .

Data siklus I menunjukan skor kemampuan berfikir kritis anak dengan rata-rata presentase yaitu $63,97 \%$. Terdapat tiga anak yang mencapai skor presentase minimal $75 \% \quad$ (TCP/Tingkat Capaian Perkembangan) Dengan kata laian hanya $25 \%$ anak yang mencapai peningkatan sesuai TCP sebesar $75 \%$ dengan kriteria mills sebesar $71 \%$.

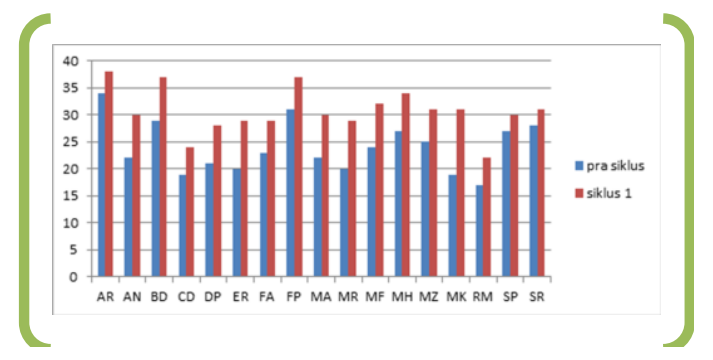

Grafik 2 : Data peningkatan kemampuan berfikir kritis anak pra siklussiklus I

Hal ini dikarenakan anak masih belum terbiasa dengan kegiatan belajar dengan pendekatan saintifik serta belum maksimalnya guru dalam memberikan materi dengan pendekatan saintifik. 


\section{Siklus II}

Tindakan pada siklus II menekankan pada keaktifan anak dalam mengeksplor secara mandiri materi pembelajaran yang di berikan. Jika pada siklus I guru masih memberikan arahan dan bantuan untuk anak, pada siklus II ini guru lebih membebeskan untuk mengesplorasi materi pembelajaran yang di berikn.

Pada siklus II kemampuan berfikir kritis anak mengalami peningkatan sebesar 89,7\%. Kemampuan mengobservasi, merumuskan masalah, menganalisis dan mengevaluasi semakin terasah dengan penerapan pendekatan saintifik. Berdasarkan siklus yang dilaksanakan selama 8 kali pertemuan, terlihat kemampuan berfikir kritis anak berkembang sangat baik dilihat adanya peningatan selama pra siklus,siklus I sampai siklus II. Hal ini berarti bahwa kemampuan berfikir kritis anak meningkat melalui pendekatan saintifik.

Data siklus II hampir semua skor mengalami peningkatan. Tingkat capaian perkembangan (TCP) kemampuan berfikir kritis anak dalam bentuk grafik mulai dari pra siklus, siklus I, hingga siklus II.

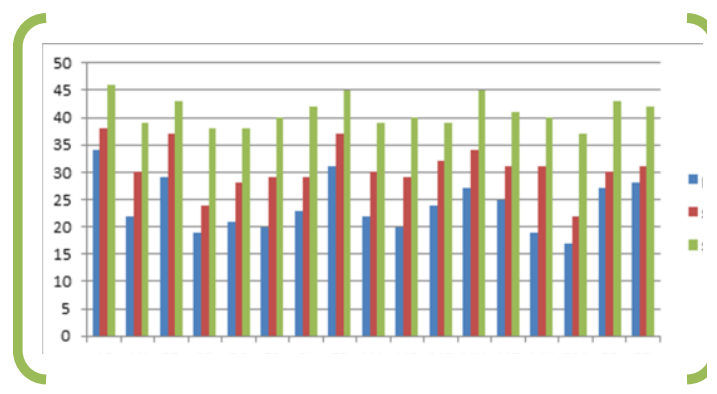

Grafik 3 : Hasil tingkat capaian perkembangan kemampuan berfikir kritis anak kelompok B di TK Pertiwi 3 Palembang
Tabel 4.15

Data peningkatan kemampuan berfikir kritis kelompok B TK pertiwi 3 Palembang

\begin{tabular}{|c|c|c|c|}
\hline Tahapan & $\begin{array}{c}\text { Pra } \\
\text { siklus }\end{array}$ & $\begin{array}{c}\text { Siklus } \\
\text { I }\end{array}$ & $\begin{array}{c}\text { Siklus } \\
\text { II }\end{array}$ \\
\hline Rata-rata & 24 & 31 & 41 \\
peningkatan & 2 & 8 & 11 \\
\hline
\end{tabular}

Dari data tabel di atas terlihat adanya peningkatan kemampuan berfkir kritis anak meningkat mulai dari pra siklus, siklu I, dan siklus II. Pada siklus II tingkat capaian anak rata-rata berada pada kategori berkembang sangat baik (BSB). Tingkat capaian perkembangan anak telah mencapai kriteria keberhasilan yang telah disepakati oleh peneliti dan kolaborator, sehingga penelitian ini dikatakan berhasil.

\section{Pembahasan}

Kegiatan pembelajaran di TK masih di dominasi Teacher Center yaitu, guru memberikan penjelasan dan anak hanya mendengarkan tanpa ada kegiatan menstimulus anak untuk berfikir kritis, dan berekspolari dalam kegiatan pembelajaran. Berfikir kritis bukanlah sebuah keterampilan yang dapat berkembang sendiri tetapi memerlukan suatu metode pengembangan khusus, yang banyak melibatkan kemampuan kognitif (Saputra, Safitri, \& Dahlan, 2017). Untuk mendorong anak berfikir kritis, dan berekspolari dalam kegiatan pembelajaran salah satunya melalui pendektan saintifik. Melalui pendekatan saintifik (saintifik Approach) anak dikenalkan pada melalui kegiatan mengamati serta menyelidiki fenomena di sekitarnya. Pendekatan scientific lebih menekankan kepada peserta anak sebagai subjek belajar yang harus dilibatkan secara aktif sepanjang kegiatan pembelajaran. anak diarahkan agar dapat mencari tahu sendiri faktap-fakta dan pengetahuan yang terkait dengan materi 
pelajaran (Ine, 2015). Hal ini didukung dengan adanya kenyataan bahwa anak usia dini sangat antusias berekspolarasi tanpa memiliki rasa takut. Pelaksanaan pendekatan saintifik beruapaya membangun suasana yang menyenangkan untuk menarik minat anak-anak berdasarkan pada prinsipprinsip perkembangan anak (Munastiwi, 2015).

Pendekatan saintifik haruslah di rancang dirancang dengan aman, dapat mengamati, menyelidiki, berketerampilan proses, bersosialisasi, dan membangkitkan motivasi dan rasa ingin tahu dengan cara yang aktif dan menyenangkan tanpa melupakan prinsip dasar anak usia dini. Menurut Yolanda (Yolanda, eric , suryana, 2013) prinsip pembelajaran dalam pendekatan saintifik guru memperhatikan anak belajar dari kenyataan, anak belajar secara nyata, mendorong anak untuk terlibat langsung dalam pengamatan, belajar dengan cara berbuat, belajar dilandasi perasaan senang, belajar bersifat menantang untuk mengasah kemampuan berpikir anak serta kegiatan pembelajarannya tidak memisahkan dari kebutuhan bermain.

Pendekatan saintifik dapat mengembangkan kemampuan berpikir anak, terutama kemampuan berfikir kritis. Melalui pendekatan saintifik anak terlibat langsung selama proses kegiatan pada saat anak terlibat dalam kegiatan main (termasuk saat kegiatan pembelajaran sains), maupun kegiatan lainnya. Dengan pembelajaran saintifik melalui $5 \mathrm{M}$ serta ketrampilan guru dalam mengelola objek belajar membantu anak dalam mengembangkan kreativitasnya. Dengan eksplorasi anak melakukan pengamatan suatu benda dan lingkungan sekitar rasa ingin tahu anak akan muncul sehingga kemampuan berfikir kritis anak juga berkembang. Dengan eksperimen dan mengumpulkan berbagai informasi dari berbagai sumber belajar anak menemukan solusi terhadap masalah serta ide baru yang belum pernah muncul. (Marwiyati, 2017).

Kemampuan berfikir kritis anak berkembang dengan sangat baik. Hal tersebut didukung oleh antusiasme anak pada setiap kegiatan yang dilakukan selama proses pembelajaran berlangsung mulai dari kegiatan mengamati, merumuskan masalah, menganalisis hingga tahapan akhir yaitu mengevaluasi. Kemampuan tersebut dapat meningkat dengan baik pada setiap pertemuannya.

\section{KESIMPULAN}

Adanya peningkatan kemmpuan berfikir kritis anak kelompok B2 melalui pendekatan saintifik. Peningktan kemampuan berfikir kritis anak terlihat ketika anak mau mengamati benda kongkrit yang akan di gunakan dalam kegiatan pembelajaran, anak mulai aktif bertanya dan mengemukakan pendapatnya mengenai benda yang mereka amati, anak mampu merumuskan masalah dengan menghubungkan sebab akibat yang mereka temui selama proses kegiatan berlangsung, Anak mampu melakukan kegiatan bercobaan secara mandiri maupun berkelompok untuk mengasah kemampuan berfikir kritis anak, anak mampu menemukan solusi untuk menyelesaikan masalah yang mereka hadapi selama proses kegiatan berlangsung, dan pada akhir pembelajaran anak mampu menarik kesimpulan akhir mengenai kegiatankegiatan yang mereka lakukan selama proses pembelajaran berlangsung.

\section{UCAPAN TERIMAKASIH}

Terimakasih kepada pihak yayasan TK Pertiwi 3 Palembang serta subjek yang telah memberikan persetujuan dan 
membantu selama proses penelitian dan pengumpulan data. Terimakasih kepada pembimbing yang banyak membantu peneliti menyempurnakan penelitian dan kepada tim editor Jurnal obsesi yang telah membantu memberikan saran, serta masukan dalam perbaikan artikel ini.

\section{DAFTAR PUSTAKA}

Azizah, N., \& Edie, S. S. (2014). Pendekatan Problem Solving Laboratory Untuk Meningkatkan Kreatifitas Dan Hasil Belajar Siswa Kelas Xi Ma Al Asror Gunungpati Semarang. Unnes Physics Education Journal, 3(3), 28-33.

Dewi, A. C., Hapidin, H., \& Akbar, Z. (2019). Pengaruh Model Pembelajaran dan Kemampuan Berpikir Kritis terhadap Pemahaman Sains Fisik. Jurnal Obsesi: Jurnal Pendidikan Anak Usia Dini, 3(1), 18. https://doi.org/10.31004/obsesi.v3i1.1 36

Ine, M. E. (2015). Penerapan Pendekatan Scientific Untukmeningkatkan Prestasi Belajar Siswa Padamata Pelajaran Ekonomi Pokok Bahasan Pasar. Prosiding Seminar Nasional $9 \mathrm{Mei}$ 2015, pp. 269-285.

Kemdikbud, K. P. (2008). Direktorat Pembinaan Pendidikan Anak Usia Dini. (021), 1-34.

Menkes, R. Pedoman Stimulasi Kognitif pada Anak Berbasis Kecerdasan Majemuk. , Pub. L. No. Nomor 62 Tahun 2015 (2015).

Moore, kenneth D. (2005). Effective Instructional Strategies: From Theory to Practice (Third Edit). London: Sage Publication.

Munastiwi, E. (2015). Implementasi Pendekatan Saintifik pada Pendidikan Anak Usia Dini (Paud). Al Athfal: Jurnal Pendidikan Anak, 1(2), 43-50. https://doi.org/10.14421/jaa.2015.12.4 3-50

Munawaroh, H., \& Retyanto, B. D. (2016). Implementasi Pendekatan Saintifik Pada Pembelajaran Cinta Lingkungan Pendidikan Anak Usia Dini (Paud) Di
Kabupaten Wonosobo. Al Athfal: Jurnal Pendidikan Anak, 2(2), 13-24. Retrieved from http://ejournal.uinsuka.ac.id/tarbiyah/index.php/alathfal/ article/view/1264

Ngalim. (2011). Evaluasi Pengajaran. Jakarta: PT Remaja Rosdakarya.

Salmon, A. K., \& Lucas, T. (2011). Exploring young children's conceptions about thinking. Journal of Research in Childhood Education, 25(4), 364-375. https://doi.org/10.1080/02568543.2011 .605206

Saputra, A. D., Safitri, N. E., \& Dahlan, U. A. (2017). Strategi Pendidikan Abad 21 Melalui Pengembangan Critical Thinking Skills Siswa Generasi Z Abstrak. I(November), 144-151.

Science, N., \& Standards, E. (1996). The national academies press. https://doi.org/10.17226/4962

Semar., Y. (2009). Investigation Critical Thingking Skills Practices in Qatari Elmentry School ,. The International Jurnal of Learning, 16, 14.

Setiawan, Hafitriani, and P. (2016). The scientific learning approach using multimedia-based maze game to improve learning outcomes. AIP Conference Proceedings. https://doi.org/10.1063/1.4941162

Tatminingsih, S. (2019). Alternatif Stimulasi Kemampuan Kognitif melalui Penerapan Model Pembelajaran Berbasis Permainan Komprehensif. Jurnal Obsesi : Jurnal Pendidikan Anak Usia Dini, 3(1), 183. https://doi.org/10.31004/obsesi.v3i1.1 30

Wartini, A., Hadi al-asy'ari, M. K., \& Multahada, A. (2017). Menggagas Model Pembelajaran DiscoveryInquiry pada Pendidikan Anak Usia Dini. Intizar, 23(1), 151-164. https://doi.org/10.19109/intizar.v23i1. 1614

Yolanda, eric , suryana, D. (2013). jurnal Yolanda, Suryana masuk bab4. Padang. 